\title{
Acral pseudolymphomatous angiokeratoma: case report and literature review*
}

\author{
Angioqueratoma pseudolinfomatoso acral: relato de caso e revisão da literatura
}

\author{
Priscila Pacheco Lessa ${ }^{1}$ \\ Flávia Regina Ferreira ${ }^{2}$ \\ Samuel Henrique Mandelbaum ${ }^{4}$
}

\author{
Juliana Chaib Ferreira Jorge ${ }^{1}$ \\ Marcia Lanzoni de Alvarenga Lira ${ }^{3}$
}

DOI: http://dx.doi.org/10.1590/abd1806-4841.20132413

\begin{abstract}
The authors describe a case of a female patient with Acral Pseudolymphomatous Angiokeratoma of Children, known as APACHE. It is a rare benign cutaneous disease, of unknown etiology, characterized by multiple, asymptomatic erythematous-violaceous papules and nodules, usually located unilaterally with acral distribution. Today, this denomination is questionable, since there are published reports of this disease in adults and in different locations. Clinically, it is similar to an angiokeratoma, whereas hystologically, it corresponds to a distinct type of pseudolymphoma. The immunohistochemical study is required to distinguish APACHE from cutaneous lymphoma.

Keywords: Child; Extremities; Hemangioma; Pseudolymphoma

Resumo: Relata-se o caso de uma paciente com diagnóstico de angioqueratoma pseudolinfomatoso acral, conhecido por sua sigla em inglês APACHE - Acral Pseudolymphomatous Angiokeratoma of Children. É uma doença cutânea benigna, rara, de etiologia desconhecida, caracterizada por múltiplas pápulas e nódulos eritêmato-violáceos assintomáticos, de localização geralmente unilateral e acral. Atualmente, questiona-se esta denominação, já que há relatos na literatura do quadro em adultos e em outras localizações. Clinicamente, é similar a um angioqueratoma, porém, histologicamente, corresponde a um tipo distinto de pseudolinfoma. $\mathrm{O}$ estudo imuno-histoquímico é necessário para diferenciação dos linfomas cutâneos.

Palavras-chave: Criança; Extremidades; Hemangioma; Pseudolinfoma
\end{abstract}

\section{INTRODUCTION}

Acral pseudolymphomatous angiokeratoma is a rare benign, cutaneous disease, mostly affecting children aged between 2 and 13. It is characterized by multiple asymptomatic erythematous-violaceous papules and nodules, usually located unilaterally with acral distribution. ${ }^{1-6}$ Initially considered a vascular malformation, today it is classed as a distinct type of pseudolymphoma. ${ }^{3,4}$ It is known by the acronym APACHE (Acral Pseudolymphomatous Angiokeratoma of Children) and was described for the first time by Ramsay in 1988. ${ }^{6}$ Currently, this denomination is under debate, as there are reported cases in the literature of adults with the condition, located in other parts of the integument. $^{1-6}$ Its etiology remains unknown. Histopathological exams reveal preserved epidermis and dense lymphocytic infiltrate in the dermis, permeating structures of the conjunctive tissue, affecting (or not) the cutaneous annexes. The immunohisto-

\footnotetext{
Received on 08.01.2013.

Approved by the Advisory Board and accepted for publication on 25.01.2013.

* Study undertaken at the University Hospital of Taubaté - University of Taubaté (HUT-UNITAU) - Taubaté (SP), Brazil. Financial Support: None

Conflict of Interest: None

MD - Specialization ( in course) at the Dermatology Service of the University Hospital of Taubate - University of Taubaté (HUT-UNITAU) - Taubaté (SP), Brazil.

Master's in Science at Federal University of São Paulo - Paulista Medical School (EPM-UNIFESP). Assistant Professor of Dermatology in the Medical Sciences department of the University of Taubaté (UNITAU) - Taubaté (SP), Brazil.

Specialist in Pathological Anatomy - Assistant Professor of Pathology in the Medical Sciences department of the University of Taubaté (UNITAU) - Taubaté (SP), Brazil.

Specialist in Dermatology - Assistant Professor of Dermatology in the Medical Sciences department of the University of Taubate (UNITAU). Head of Dermatology at the University Hospital of Taubaté - University of Taubaté (HUT-UNITAU) - Taubaté (SP), Brazil. 
chemical study is necessary in order to distinguish the cutaneous lymphomas. ${ }^{1-7}$ The elective therapeutic choice is total excision of lesions but intralesional corticotherapy, cryotherapy and radiotherapy are also described, though they entail recurrence. ${ }^{2}$

\section{CASE REPORT}

White, female patient, aged 11, complaining of "small lumps on the left wrist since the age of two". The dermatological exam revealed erythematous-violaceous papules on the left wrist, which appeared fainter during the vitropression test (Figure 1). The condition had been evolving for 9 years, without any changes in clinical characteristics, local symptomatology or previous trauma. The histopathological exam revealed an integral epidermis without atypia; and, in the dermis, inflammatory infiltrate of superficial and deep, perivascular location, around the pilo-erector muscles, hair follicles, eccrine glands and nerves (Figures 2 and 3A). The infiltrate was made up of lymphocytes, some histiocytes, a moderate number of plasmocytes and small basophilic granulations in the cytoplasmas of the histiocytic cells. Infiltration was noticed in the hypodermal lobules. The search for alcohol-acid resistant bacilli using the Ziehl-Neelsen staining procedure culminated in a negative result. In regard to the inflammatory infiltrate, abundant in plasmocytes, a clinical and laboratory investigation was conducted to rule out leishmaniasis and syphilis, with the following findings: non-reactive VDRL and FTA-Abs results (Figure 3B). Surveys for micobacteria, treponema and leishmania, by immunohistochemistry, produced negative results. In addition: hemogram, hepatic and renal function, ESR, dosage of immunoglobulins and protein electrophoresis, without changes.

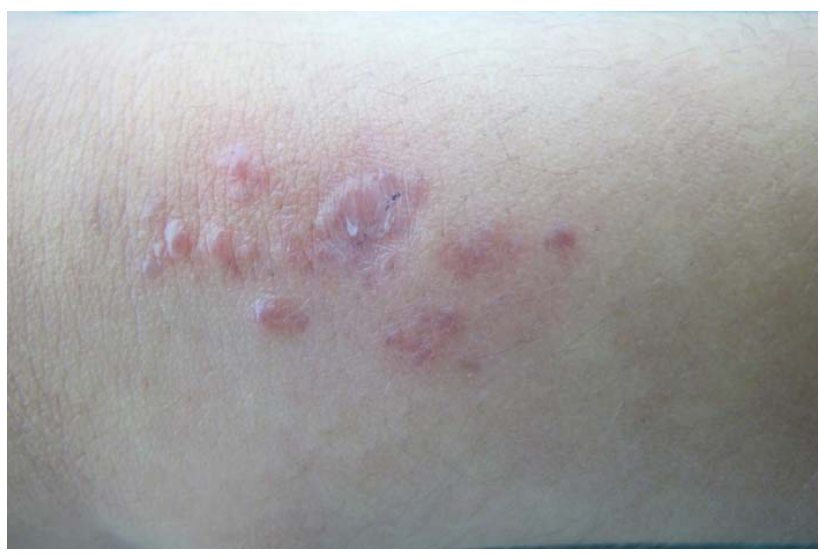

FIGURE 1: Left wrist - grouped erythematous-violaceous papules

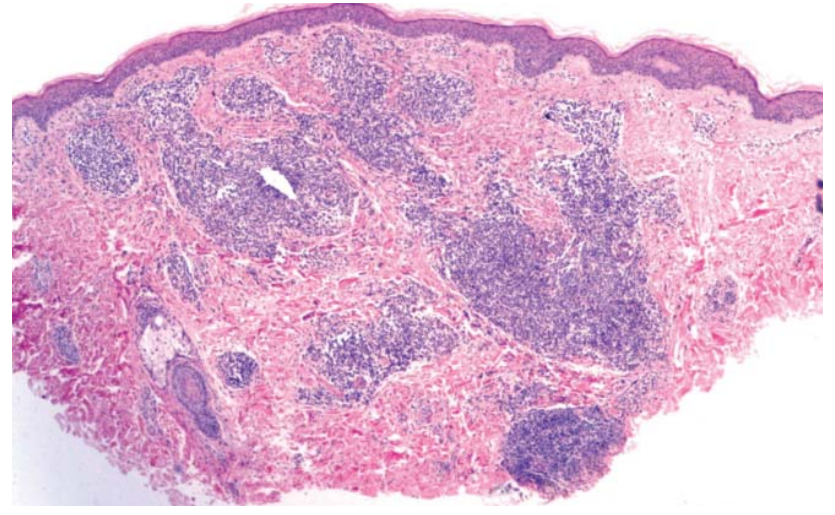

FIGURE 2: Dense lymphomononuclear infiltrate of plexiform pattern (HE, 40x)
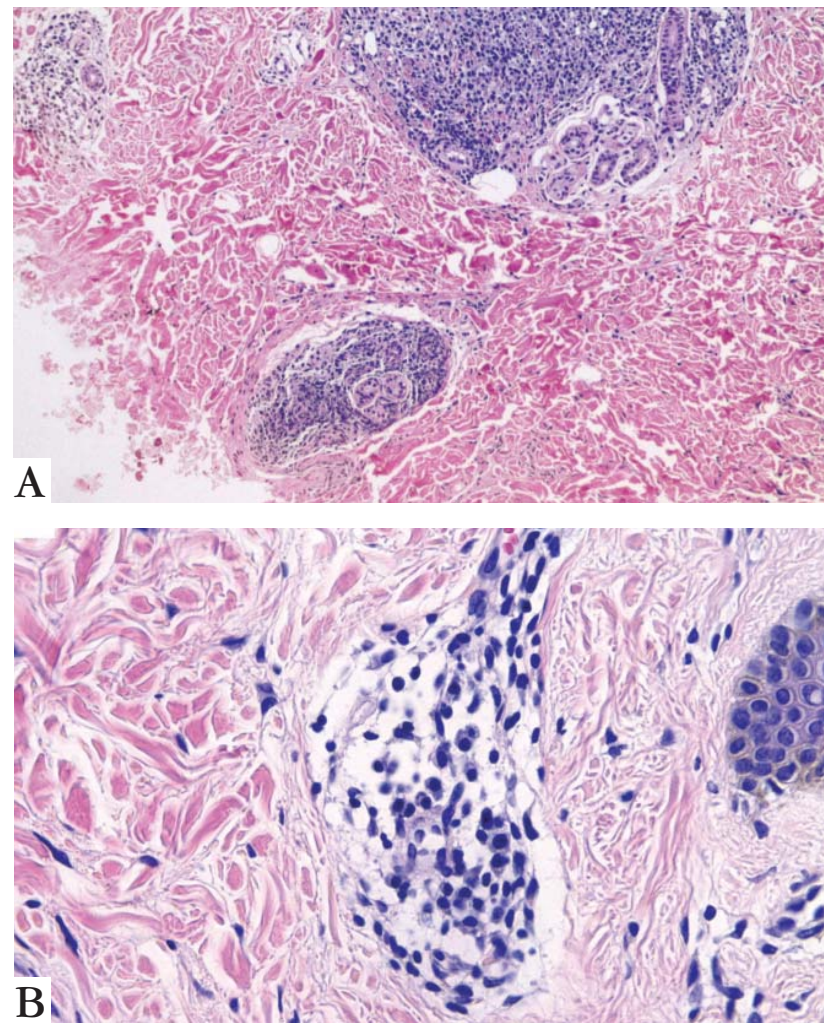

Figure 3: A. Infiltrate occupying the deep dermis (HE, 100x); B. Infiltrate composed of plasmocytes (HE, 400x)

Thus, total excision of the lesions was initiated, to diagnostic and therapeutic ends. The histopathological exam revealed the same histopatholoogical pattern as before. The immunohistochemical study of the biopsy material revealed histological characteristics of dermal lymphoid proliferation of small, perivascular and adnexal, $\mathrm{T}$ and $\mathrm{B}$ lymphocytes, with a low proliferative index (Figure 4 and Chart 1 ).

The patient is undergoing outpatient follow-up, with no signs of recurrence at present. 

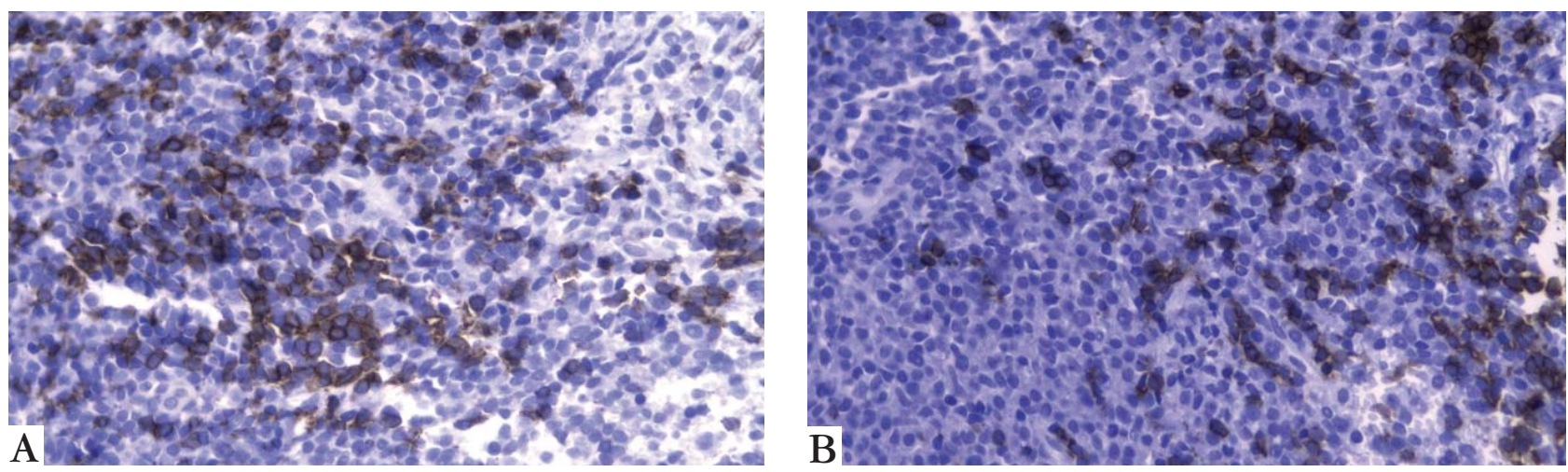

Figure 4: Immunohistochemical panel: A. Anti-CD20 (400x). B. Anti-CD8 (400x)

CHART 1: Immunohistochemical panel

\begin{tabular}{|lll|}
\hline Markers- Antibodies & Clone & Expression \\
\hline Ki-67 & SP6 & Positive in 5\% of cells \\
Cyclin D1 & EP12 & Negative (internal positive control) \\
CD8 & C8/144B & Positive in several small lymphocytes \\
CD7 & MRQ-12 & Positive in several small lymphocytes \\
CD4 & $4 B 12$ & Positive in numerous small lymphocytes \\
CD3 & F7.2.38 & Positive in numerous small lymphocytes \\
CD23 & 1B12 & Positive in few dendritic follicular cells \\
CD20 & L26 & Positive in several small lymphocytes \\
CD10 & $56 C 6$ & Negative (internal positive control ) \\
B1-2 & Bcl-2-100 & Positive in numerous small lymphocytes \\
\hline
\end{tabular}

\section{DISCUSSION}

Acral pseudolymphomatous angiokeratoma, known by the acronym APACHE (Acral Pseudolymphomatous Angiokeratoma of Children), is a rare entity, first described by Ramsay et al in 1988. Since then, approximately 25 cases have been described in the literature. ${ }^{?}$

Initially considered a vascular malformation, today it is classed as a distinct type of pseudolymphoma. Immunohistochemical studies of cell markers and gene receptors using Southern blotting analysis have shown the poyclonal nature of the cellular infiltrate.

Its etiology remains unknown. Many authors consider that terms such as "papular angiolymphoid hyperplasia", "acral angiokeratoma-like pseudolymphoma" and "pseudolymphomatous angiokeratoma", are more appropriate given that there have been cases involving different locations and age groups. ${ }^{2,6}$

Clinically, it is characterized by asymptomatic, grouped erythematous-violaceous papules and nodules, of angiomatous character and a keratotic surface, located mainly in the extremities of children aged between 2 and 13. ${ }^{1-6}$

In a recent review of reported APACHE cases, Tokuda et al found that $77 \%$ of patients were female, $52 \%$ of lesions were acral and $70 \%$ of the affected individuals were made up of children and adolescents. ${ }^{7}$

Histologically, it presents with dense inflammatory infiltrate made up of lymphocytes, histiocytes, plasmocytes, multinucleated giant cells and a varying number of eosinophils (Chart 2) ${ }^{5,6}$ The infiltrate may (or not) affect annexes. Histological changes can affect the epidermis, revealing variable inflammatory changes such as exocytosis, vacuolar changes, spongiosis and eosinophilic bodies, though the meaning of these histological changes is still unknown. ${ }^{7}$

An immunohistochemical study is needed to rule out cutaneous lymphomas. ${ }^{2}$ It reveals $\mathrm{B}$ and $\mathrm{T}$ lymphocytes (CD4 and CD8) staining., ${ }^{4,5}$ Some reports indicate a predominance of $\mathrm{T}$ cells over $\mathrm{B}$ cells in the adult population, while the reverse is reported among 
СHART 2: Histopathological findings of the studies cited

\begin{tabular}{|c|c|}
\hline Study & Histopathological findings \\
\hline \multirow[t]{4}{*}{ Ramsay et al } & Presence of hyperkeratosis in the epidermis. \\
\hline & $\begin{array}{l}\text { Dense infiltrate with lymphocytes, plasmocytes and some histiocytes, in the dermis. Extension to hypo- } \\
\text { dermis. }\end{array}$ \\
\hline & Blood vessels with thick walls. \\
\hline & Swollen endothelial cells. \\
\hline Freire et al & $\begin{array}{l}\text { Normal epidermis, dense inflammatory lymphocytic infiltrate permeating structures of the conjunctive } \\
\text { tissue of the dermis, but without affecting the cutaneous annexes, showing nodular lymphocytic proli- } \\
\text { feration. }\end{array}$ \\
\hline \multirow[t]{3}{*}{ Okada et al } & Band-like dense inflammatory infiltrate composed of lymphocytes, histiocytes, plasmocytes. \\
\hline & Blood vessels with thick walls. \\
\hline & Epidermal changes. \\
\hline \multirow[t]{2}{*}{ Murakami et al } & Presence of dense inflammatory infiltrate without atypia, and occasional histiocytes and plasmocytes. \\
\hline & Swollen endothelial cells. \\
\hline \multirow[t]{3}{*}{ Hagari et al } & $\begin{array}{l}\text { Dense inflammatory infiltrate made up of lymphocytes, histiocytes, eosinophils and a small number of } \\
\text { multinucleated giant cells. }\end{array}$ \\
\hline & Liquefaction necrosis of the basal cell layer. \\
\hline & Blood vessels with thick walls. \\
\hline \multirow[t]{2}{*}{ Chedraoui et al } & Band-like dense inflammatory infiltrate composed of lymphocytes, histiocytes, plasmocytes. \\
\hline & Blood vessels with thick walls. \\
\hline \multirow[t]{3}{*}{ Tokuda et al } & $\begin{array}{l}\text { Epidermal alterations: hyperkeratosis without parakeratosis, discrete spongiosis, partial vacuolar alte- } \\
\text { ration and lymphocyte exocytosis. }\end{array}$ \\
\hline & Dense inflammatory infiltrate below the epidermis at the transition to the reticular dermis. \\
\hline & Lymphocytic infiltrate in the dermis, showing nodular lymphocytic proliferation. \\
\hline
\end{tabular}

the pediatric population. ${ }^{6}$ Studies with polymerase chain reaction (PCR) showed the polyclonality of the inflammatory infiltrate, thus suggesting the reactional process of this entity. ${ }^{4,5,6}$

Tokuda et al., through an immunostaining study of the lesion's vessels, obtained positive results for specific markers of the endothelium of the lymphatic vessels (podoplanin) and blood vessels (CD 34).
Linking these findings to the epidemiology of the disease, they again considered the hypothesis that the histogenesis of APACHE could be a type of vascular malformation or hemangioma. ${ }^{7}$

The elective therapeutic choice is total excision of the lesion, but intralesional corticotherapy, cryotherapy and radiotherapy are also described, though they entail recurrence. $\left.{ }^{2}\right]$ 


\section{REFERENCES}

1. Ramsay B, Dahl MC, Malcolm AJ, Wilson-Jones E. Acral pseudolymphomatous angiokeratoma of children. Arch Dermatol. 1990;126:1524-5.

2. Freire FMZ, Filho JBS, Cintra LC, Diniz LM. Acral pseudolymphomatous angiokeratoma - a case report. An Bras Dermatol. 2006;81:S277-80.

3. Okada M, Funayama M, Tanita M, Kudoh K, Aiba S, Tagami H. Acral angiokeratoma-like pseudolymphoma: one adolescent and two adults. J Am Acad Dermatol. 2001;45:S209-11.

4. Murakami T, Ohtsuki M, Nakagawa H. Acral pseudolymphomatous angiokeratoma of children: a pseudolymphoma rather than an angiokeratoma. Br J Dermatol. 2001;145: 512-4.

5. Hagari Y, Hagari S, Kambe N, Kawaguchi T, Nakamoto S, Mihara M. Acral pseudolymphomatous angiokeratoma of children: immunohistochemical and clonal analyses of the infiltrating cells. J Cutan Pathol. 2002;29:313-8.

6. Chedraoui A, Malek J, Tamraz H, Zaynoun S, Kibbi AG, Ghosn S. Acral pseudolynphomatous angiokeratoma of children in an elderly man: report of a case and review of the literature. Int J Dermatol. 2010;49:184-8.

7. Tokuda Y, Arakura F, Murata H, Koga H, Kawachi S, Nakazawa K. Acral pseudolynphomatous angiokeratoma of children: A case report with immunohistochemical study of antipodoplanin antigen. Am J Dermatopathol. 2012;34:e128-32.

\author{
MAILING ADDRESS: \\ Flávia Regina Ferreira \\ Avenida Granadeiro Guimarães, 270 - Centro \\ 12020-130 - Taubaté - SP \\ Brazil \\ E-mail: dermagica@uol.com.br
}

How to cite this article: Lessa PP, Ferreira Jorge JC, Ferreira FR, Alvarenga Lira ML, Mandelbaum SH. Acral pseudolymphomatous angiokeratoma: case report and literature review. An Bras Dermatol. 2013;88(6 Suppl 1):S39-43. 